\title{
Visibly enlarged peripheral nerves in lepromatous leprosy
}

Joy Zhuo Ding, MD, and Pedro Legua, MD

Neurology ${ }^{\circledR}$ 2019;92:627-628. doi:10.1212/WNL.0000000000007239

A 52-year-old man from the Peruvian jungle presented with a 4-year history of progressive distal numbness and facial swelling. He had diffusely infiltrated skin on his face, torso, and extremities (figure, A and B), with patchy pinprick sensation loss. Multiple peripheral nerves were palpable, including ulnar and fibular nerves, in addition to visibly enlarged great auricular (figure, $\mathrm{C}$ ) and superficial radial nerves (figure, D).

Slit skin smears showed up to 5+ acid-fast bacilli. Skin biopsy was compatible with lepromatous leprosy, strongly positive with Fite-Faraco staining.

Enlargement of peripheral nerves in leprosy is well-described; however, hypertrophy visible to the naked eye is rarely photographed.

\section{Author contributions}

J.Z. Ding: manuscript conception, drafting, and editing and taking clinical photographs. P. Legua: manuscript editing and clinical care of the patient.

\section{Study funding}

No targeted funding reported.

\section{Disclosure}

The authors report no disclosures relevant to the manuscript. Go to Neurology.org/ $\mathrm{N}$ for full disclosures.

\author{
Correspondence \\ Dr. Ding \\ joy.ding@medportal.ca
}

From the Division of Neurology (J.Z.D.), The Ottawa Hospital, Canada; Instituto de Medicina Tropical "Alexander von Humboldt" (P.L.), Universidad Peruana Cayetano Heredia; and Departamento de Enfermedades Infecciosas, Tropicales y Dermatologicas (P.L.), Hospital Cayetano Heredia, Lima, Peru.

Go to Neurology.org/N for full disclosures. 

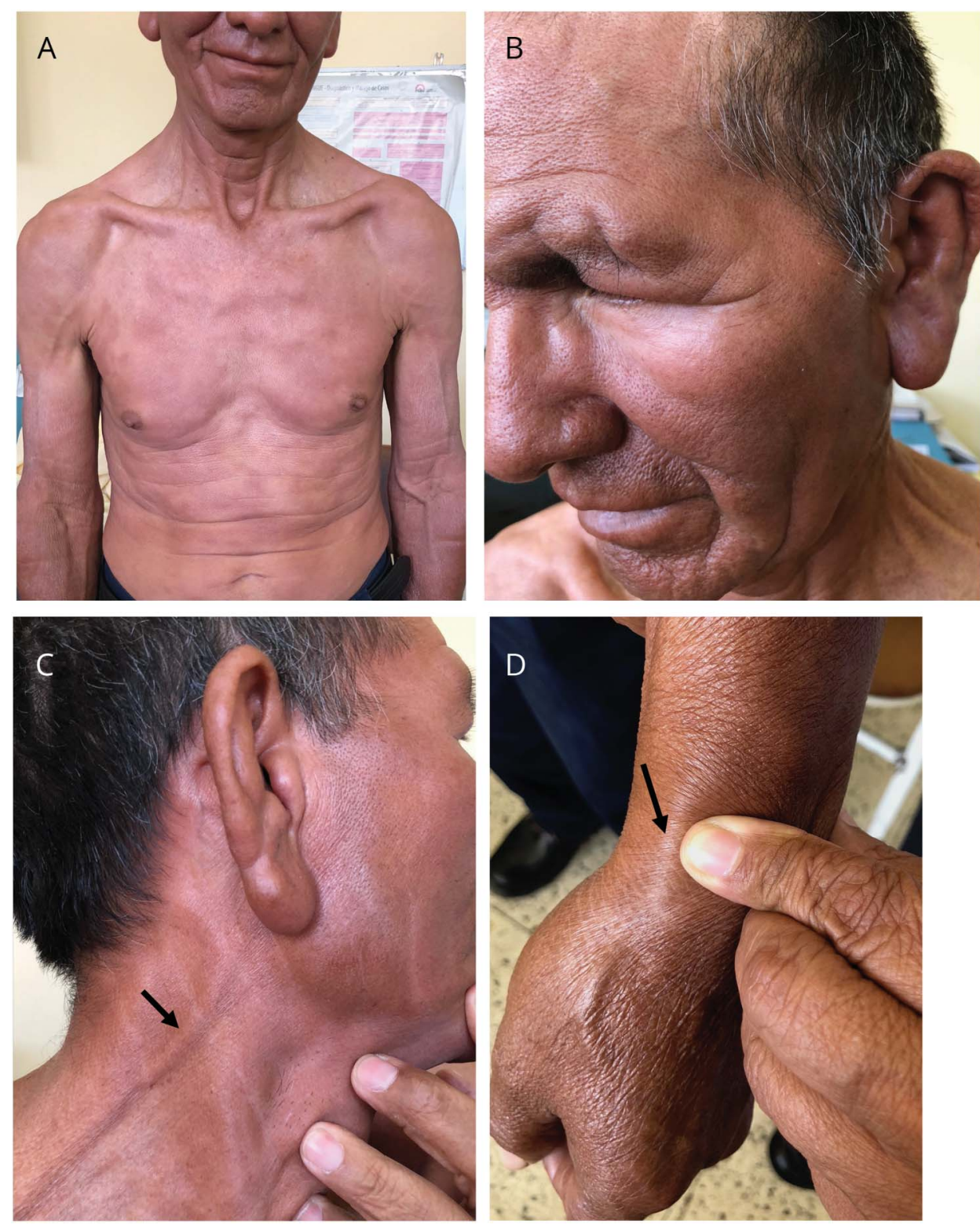

(A) Diffusely infiltrated and erythematous skin. (B) Diffuse infiltration of the face with loss of eyebrows. (C) Visibly enlarged greater auricular nerve; also note the enlarged earlobe. (D) Visibly enlarged superficial radial nerve.

\section{Are You Ready?}

The MACRA's new Quality Payment Program is now in effect. Learn about your payment and reporting options under the Merit-based Incentive Payment System (MIPS) and Advanced Alternative Payment Models (APMs) and what you need to know to do now to ensure your success. Learn more at $A A N$.com/view/QPP and sign up to receive timely updates. 


\title{
Neurology
}

\author{
Visibly enlarged peripheral nerves in lepromatous leprosy \\ Joy Zhuo Ding and Pedro Legua \\ Neurology 2019;92;627-628 \\ DOI 10.1212/WNL.0000000000007239
}

This information is current as of March 25, 2019

\section{Updated Information \& Services}

\section{Subspecialty Collections}

Permissions \& Licensing

Reprints including high resolution figures, can be found at: http://n.neurology.org/content/92/13/627.full

This article, along with others on similar topics, appears in the following collection(s):

All global neurology

http://n.neurology.org/cgi/collection/all_global_neurology

Bacterial infections

http://n.neurology.org/cgi/collection/bacterial_infections

Clinical neurology examination

http://n.neurology.org/cgi/collection/clinical_neurology_examination EMG

http://n.neurology.org/cgi/collection/emg

Peripheral neuropathy

http://n.neurology.org/cgi/collection/peripheral_neuropathy

Information about reproducing this article in parts (figures,tables) or in its entirety can be found online at:

http://www.neurology.org/about/about_the_journal\#permissions

Information about ordering reprints can be found online:

http://n.neurology.org/subscribers/advertise

Neurology ${ }^{\circledR}$ is the official journal of the American Academy of Neurology. Published continuously since 1951, it is now a weekly with 48 issues per year. Copyright (O 2019 American Academy of Neurology. All rights reserved. Print ISSN: 0028-3878. Online ISSN: 1526-632X.

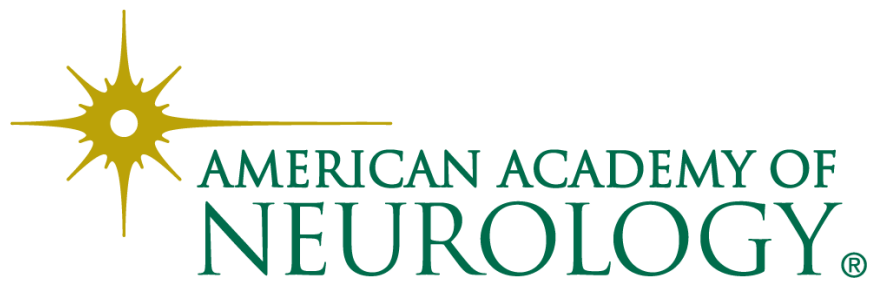

